References:

[1] Candido R, et al. Circulation 2004;109:1536-1542.

[2] Zhang F et al, Sci Rep. 2016; 6: 34621.

[3] Villalobos LA et al, Front Pharmacol. 2016; 7: 482

Disclosure of Interest: None declared

DOI: 10.1136/annrheumdis-2017-eular.5493

\section{AB0087 SONIC HEDGEHOG PROMOTES FIBROBLAST-LIKE SYNOVIOCYTES PROLIFERATION VIA MODULATING THE MAPK/ERK SIGNALING PATHWAY IN RHEUMATOID ARTHRITIS}

F. Liu ${ }^{1}$, S.-L. Zhu ${ }^{2}$, Y.-F. Pan ${ }^{1}$, J.-L. Huang ${ }^{2} .{ }^{1}$ Rheumatology, the Third Affiliated Hospital of Sun Yat-Sen University; ${ }^{2}$ Rheumatology, the Sixth Affiliated Hospital of Sun Yat-Sen University, Guangzhou, China

Background: The Sonic hedgehog (Shh) signaling has been reported to be activated in synovium of RA patients and RA-FLS in vitro [1]. Further, Shh signaling plays an important role in RA-FLS proliferation [2]. As for the extracellular signal-regulated kinase (ERK), is a member of mitogen-activated protein kinase (MAPK) [3], which has been reported to be involved in proliferation of RA-FLS [4]. However, the role of MAPK/ERK signaling pathway in the proliferation of RA-FLS modulating by Shh is unclear.

Objectives: To study the effect of MAPK/ERK signaling pathway on cell proliferation modulated by Sonic hedgehog (Shh) signaling in fibroblast-like synoviocytes isolated from patients with active rheumatoid arthritis (RA-FLS).

Methods: The RA-FLS were primarily cultured by the explant culture, and then were treated with Shh agonist Purmorphamine,inhibitor Cyclopamine or MAPK/ERK signaling pathway inhibitor U0126, respectively. Western blots was used to examine the phosphorylation level of ERK 1/2 (p-ERK1/2), which was the critical protein of MAPK/ERK signaling. The cell proliferation activity was detected using cell proliferation and cytotoxicity kit-8 (CCK8), and the cell proliferation rate was detected using a flow cytometry.

Results: Compared with the control group, Purmorphamine transiently increased p-ERK $1 / 2$ protein at the concentration of $1 \mu \mathrm{M}$, and the peak activations of p-ERK $1 / 2$ took place at $15 \mathrm{~min}(P<0.01)$. Cyclopamine and $\mathrm{U} 0126$ decreased the expression of $\mathrm{p}$-ERK $1 / 2$ protein $(P<0.01)$. After the RA-FLS treated with Purmorphmine $(1 \mu \mathrm{M})$ for 48 hours, the cell proliferation activity was $114 \pm 4 \%$ and the percentage of $S$ phase cells was $8.39 \pm 0.60 \%$, significantly higher than those of the control group $100 \pm 0 \%(P<0.01)$ and $3.29 \pm 0.69 \%(P<0.01)$. After treated with Cyclopamine $(10 \mu \mathrm{M})$ for 48 hours, the cell proliferation activity of RA-FLS was $89 \pm 1 \%(P<0.05)$ and the percentage of $S$ phase cells was $1.53 \pm 0.22 \%$ $(P<0.05)$. When co-treated with purmorphamine $(1 \mu \mathrm{M})$ and $\mathrm{U} 0126(10 \mu \mathrm{M})$, the cells proliferative activity was $892 \%(P<0.05)$ and the percentage of $S$ phase cells was $1.07 \pm 0.25 \%(P<0.05)$.

Conclusions: Shh might promote proliferaton of RA-FLS via modulating MAPK/ERK signaling, subsequently contributing to hyperlasia of synovium and ultimately leading to RA disease.

References:

[1] Wang M, et al. Sonic hedgehog signaling drives proliferation of synoviocytes in rheumatoid arthritis: a possible novel therapeutic target[J]. J Immunol Res, 2014, 2014: 401903.

[2] Zhu SL, et al. Inhibition of smoothened decreases proliferation of synoviocytes in rheumatoid arthritis[J]. Cell Mol Immunol, 2015. DOI: 10.1038/cmi.2015.67.

[3] Elia D, et al. Sonic hedgehog promotes proliferation and differentiation of adult muscle cells: Involvement of MAPK/ERK and PI3K/Akt pathways[J]. Biochim Biophys Acta, 2007. 1773(9): 1438-46.

[4] Morel J, Audo R, Hahne M, Cet al. umor necrosis factor related apoptosis inducing ligand (TRAIL) induces rheumatoid arthritis synovial fibroblast proliferation through mitogen activated protein kinases and phosphatidylinositol3kinase/Akt[J]. J Biol Chem 2005. 280(16):15709-15718.

Acknowledgements: This study was supported by the National Natural Science Foundation of China (No.81571584). I thank Jianlin Huang for protocols.

Disclosure of Interest: None declared

DOI: 10.1136/annrheumdis-2017-eular.4027

\section{AB0088 THE ROLE OF HIGH MOBILITY GROUP BOX-1 (HMGB1) IN INFLAMMATORY VASCULOPATHY IN COLLAGEN ANTIBODY-INDUCED ARTHRITIS (CAIA)}

F. Biscetti ${ }^{1}$, A. Flex ${ }^{2}$, F. Angelini ${ }^{2}$, E. Gremese ${ }^{1}$, B. Tolusso ${ }^{1}$, G. Ferraccioli ${ }^{1}$ ${ }^{1}$ Rheumatology; ${ }^{2}$ Internal Medicine, Catholic University School of Medicine, Rome, Italy

Background: Rheumatoid arthritis (RA) is associated with vascular disease (1). Recent findings demonstrated that the risk of peripheral arterial occlusive disease is increased in patients with RA compared to the general population (2). However, the pathogenesis is not fully understood. High-mobility group box-1 (HMGB1) is a nuclear protein involved in inflammatory responses (3) and RA-like synovitis (4). Objectives: Aim of the present study was to analyze the relationship between HMGB1 and peripheral arterial disease in collagen antibody-induced arthritis (CAIA).

Methods: BALB/c mice were injected with monoclonal anti-collagen antibody cocktail followed by lipopolysaccharide to induce arthritis. After the induction of arthritis, we studied ischemia-induced neovascularization in the ischemic hind limb of arthritic and control mice.

Results: We found that the perfusion recovery was significantly attenuated arthritic mice, compared to control mice. The immunohistochemical analysis for the CD31 demonstrated a reduced number of vessel in mice with experimental arthritis. The selective blockade of HMGB1 in arthritic mice resulted in restored blood flow recovery and capillary density in the ischemic muscle. Cytokine enzyme-linked immunosorbent assay (ELISA) analyses performed on peripheral blood demonstrated a significant reduction of interleukin (IL)-1 $\beta$, IL-6 and tumor necrosis factor (TNF)- $\alpha$ in mice where HMGB1 was blocked. Interestingly, the selective blockade of HMGB1 resulted in an increase of the peripheral IL-17A concentration.

Conclusions: HMGB1 pathway is involved in an experimental vasculopathy induced in a RA-like model. The proangiogenic cytokine IL-17A is increased when HMGB1 is inhibited. Although further data are needed, these findings provide new evidence regarding the pathogenesis of vascular complications observed in patients with RA.

\section{References:}

[1] Roman MJ, Salmon JE. Cardiovascular manifestations of rheumatologic diseases. Circulation. 2007 Nov 13;116(20):2346-55.

[2] Chuang YW, Yu MC, Lin CL, Yu TM, Shu KH, Huang ST, Kao CH. Risk of peripheral arterial occlusive disease in patients with rheumatoid arthritis. A nationwide population-based cohort study. Thromb Haemost. 2016 Jan;115(2):439-45.

[3] Biscetti F, Ghirlanda G, Flex A. Therapeutic potential of high mobility group box-1 in ischemic injury and tissue regeneration. Curr Vasc Pharmacol. 2011 Nov:9(6):677-81.

[4] Biscetti F, Flex A, Pecorini G, Angelini F, Arena V, Stigliano E, Gremese E, Tolusso B, Ferraccioli G. The role of high-mobility group box protein 1 in collagen antibody-induced arthritis is dependent on vascular endothelial growth factor. Clin Exp Immunol. 2016 Apr;184(1):62-72.

Disclosure of Interest: None declared

DOI: 10.1136/annrheumdis-2017-eular.4111

\section{AB0089 ELECTROKINETIC CHARACTERISTICS OF SYNOVIOCYTES (SC) AND THE LEVEL OF ANTIOXIDANT PROTECTION IN RHEUMATOID ARTHRITIS (RA)}

G. Kudriavtseva, V.I. Shishkin, V.V. Shishkin, Y.A. Malenkov. Saint Petersburg State University, Saint Petersburg, Russian Federation

Background: Known role of SC in the pathogenesis of RA. It is impossible, however, at this level of knowledge to ascertain all the mechanisms for their involvement in the pathological process. Reduced tissue antioxidant protection can affect cellular metabolism, and as might be expected, through the mechanism of autophagy inducing mitochondrial and lysosomal degradation, facilitating cell membrane depolarization.

Objectives: The aim of this work was to study the electrophoretic mobility (EM) of $\mathrm{SC}$ of RA patients and its relationship with the activity of antioxidant enzymes: Cu-Zn superoxidismutase (Cu-Zn SOD), Se-glutathione peroxidase (Se-GPO) and catalase (the CAT) in synovial fluid (SF).

Methods: SF has been obtained from the knee of 7 patients with RA and 5 donors. SC isolated by standard methods. EM of SC determined by the automatic microscope. Se level in SF recorded by atomic absorption spectrometry. The activity of the antioxidant enzymes was determined by classical methods of enzymology.

Results: A significant depolarization of the RA SC, resulting in a reduction of their EM as compared to the normal level of the average in 4 times. Activity of antioxidant enzymes is dramatically reduced by a significant decrease of Se concentrations in SF $(150 \mu \mathrm{g} / \mathrm{l}$ normally up to $80 \mu \mathrm{g} / \mathrm{l}$ in RA), which is particularly reflected in the activity of Se GPO (note that SF can be up to 100 Se-containing proteins).

\begin{tabular}{lcccc} 
Table 1 & \multicolumn{5}{c}{} \\
\hline & $\begin{array}{l}\text { EM of SC } \\
(\mathrm{m} / \mathrm{v} \mathrm{sec})\end{array}$ & $\begin{array}{c}\text { Cu-Zn SOD } \\
(\text { Units } / \mathrm{mg} \text { of protein })\end{array}$ & $\begin{array}{c}\text { Se-GPO } \\
(\text { Units } / \mathrm{mg} \text { of protein })\end{array}$ & $\begin{array}{c}\text { CAT } \\
(\mu \mathrm{mol} / \mathrm{min} / \mathrm{mg} \text { of protein) }\end{array}$ \\
\hline Normal SF & $1,62 \times 10^{-8}$ & $23,4 \pm 0,8$ & $1,3 \pm 0,3$ & $10,3 \pm 0,1$ \\
RA SF & $0,37 \times 10^{-8}$ & $11,7 \pm 0,4$ & $0,4 \pm 0,1$ & $0,47 \pm 0,04$ \\
\hline
\end{tabular}

Conclusions: We can assume that aggravated by RA catabolic processes that caused the dysfunction of the lysosomal and mitochondrial structures (autophagy), consistently shoot antioxidant protection of SC and cause depolarization and the decrease in electrophoretic mobility of these cells.

Disclosure of Interest: None declared

DOI: 10.1136/annrheumdis-2017-eular.5364 